\title{
Originalartikel
}

\section{Uvished i ungeliv med en alvorligt syg forælder}

\section{Ditte Winther-Lindqvist}

\author{
Dansk Pædagogisk Universitet/Aarhus Universitet \\ diwi@edu.au.dk
}

Winther-Lindqvist, Ditte (2018). 'Uvished i ungeliv med en alvorligt syg forælder', Tidsskrift for Forskning i Sygdom og Samfund, nr. 29, 55-76

Artiklen formidler resultater fra en kvalitativ interviewundersøgelse med teenagere, der har en alvorligt somatisk syg forælder. Analysen er foretaget på baggrund af kultur-historisk udviklingspsykologi og eksistensfænomenlogi mhp. at afdxkke betydningen af livet med sygdom for de unges hverdagsliv, oplevelsesverden og sociale udviklingssituation. Undersøgelsens hovedresultat er, at de unges liv forandres eksistentielt, praktisk, emotionelt og socialt, fordi de lever med uvished om forælderens overlevelse og sygdommens forløb. Det betyder, at de udvikler strategier, der kan hjælpe dem med at øge kontrollen med konfrontationer med sygdommen og fastholde et engagement $i$ ungelivets aktiviteter og projekter. Strategierne er at skabe sig hvilepauser og lave skarpe opsplitninger mellem privat og social væren og livet ude og hjemme i familien. Det mulige tab af forælderen ændrer de unges eksistentielle horisont og afslører, at vi $i$ almindelighed lever med forestillingen om en fremtid sammen med vores nærmeste $i$ sammenvævede livstider. Denne forventning mister de unge pårørende, hoilket påvirker deres motiver således, at motivet mod deltagelse i ungelivets aktiviteter ledsages af et konkurrerende motiv om at være hjemme ved den syge forælder og støtte familien og eller opnå samhørighed med den syge forælder. Deres ny eksistentielle, emotionelle, praktiske og sociale virkelighed betyder, at de befinder sig $i$ et anstrengende pres, som skaber afstand til de jæonaldrende. Der argumenteres for, at de unge parrorende af disse grunde befinder sig $i$ en anden social udviklingssituation end deres jæonaldrende med raske forældre. 


\section{Uncertancy for youngsters with a seriously ill parent}

The article is based on a qualitative interview study with teenagers who have a somatically fatally ill parent. The main result is that the teenagers' lives changes in various ways, yet they have in common to live in a radical uncertainty about their parents' illness, its duration and survival. This shared life condition is analyzed multi-theoretically with concepts from cultural-historical developmental psychology and questions from existential phenomenology. The analysis aims at exploring both developmental issues of everyday life activities, motives and projects, as well as more existential themes motivated by the threat of losing the parent. The teenagers employ strategies in order to maintain their engagements in everyday life, by creating pauses, and firm splits between their social and private being, and their home life and life outside the family. The teenagers seem to develop a competing motive to their youth-life in staying home, and taking care of the parent(s) and family which means that they find themselves in a draining dilemma with regards to their peers. Given all the changes that follow from living with serious illness in a parent, existentially, emotionally, socially and practically the teenagers find themselves different from and singled out from their peers. For those reasons, it is argued that this group of teenagers are in a different social situation of development, from their peers with parents of good health.

\section{Indledning}

Grundet store medicinske fremskridt er flere somatiske sygdomme, som før var dødelige inden for en kort tidshorisont, i dag til at behandle så folk overlever længere, og også stadig flere helbredes. Denne positive udvikling betyder imidlertid, at flere børn og unge lever med sygdom $\mathrm{i}$ familien henover mange år og $\mathrm{i}$ visse tilfælde gennem alle deres teenageår. Hvad betyder det for de unge at leve med en alvorligt syg forælder? Kan vi sige noget om, hvordan det påvirker ungelivet og udviklingen, og hvilke problemstillinger og udfordringer der er særligt fremtrædende for denne gruppe? Den psykologiske forskning om unge som pårørende til somatisk syge forældre viser i den vestlige verden langt fra entydige resultater i forhold til, hvordan forælderens sygdom får betydning for de unges udvikling, trivsel og mistrivsel. Nogle studier har vist, at denne gruppe typisk har lavere selvværd, føler sig mere ensomme, har flere skyldfølelser, har dårligere skoleresultater, højere angst niveauer, forøget risiko for selvmodsforsøg, og generelt lavere trivsel end deres jævnaldrende med raske forældre (Christ et al. 2002, Grabiak et al. 2007, Woodring et. Al. 2005). Endvidere fremgår det bl.a., at der er en tendens til rolle- og ansvarsforskydninger i familier med sygdom, og at de unges trivsel forværres, når forældrene er stærkt belastede af forløbet (Dyregrov 2012). Sygdom 
rammer i alle slags familier med vidt forskellige ressourcer (økonomisk, socialt, netværksmæssigt), hvilket formodentlig er grunden til at en hel del studier ikke kan vise nogle signifikante forskelle på pårørendes trivsel sammenlignet med unges trivsel, når de har raske forældre (Berggren \& Hanson 2016). Med andre ord er der stor forskel på, hvad sygdommen betyder i familiens samlede liv, og hvor belastende sygdommen er for de pårørende børn. I et repræsentativt dansk survey angiver flertallet af de unge pårørende til syge forældre, at de trives godt (82,8 pct) (Nielsen et al 2010). Til gengæld er det påvist, at de unges trivsel forværres markant, hvis der er øvrige risikofaktorer til stede i deres liv - ikke mindst i tilfælde af ko-morbiditet, hvis f.eks. den somatisk syge forælder eller ægtefælle udvikler en depression (Grabiak 2007). Den kvantitative forskning afdækker, hvilke symptomer de unge pårørende typisk har, og kan vise overordnede sammenhænge mellem forskellige omstændigheders indflydelse på trivslen, men giver ikke meget indsigt i, hvad de unge selv oplever som mest belastende, på hvilke måder og af hvilke grunde.

Undersøgelsen som danner baggrund for denne artikel har som hovedresultat, at livet som pårørende til en alvorligt syg forælder sætter de unge i et felt af uvished - og det er denne uvished, som udgør et alvorligt slag i livet for de unge pårørende i form af en eksistentiel modifikation (Winther-Lindqvist 2014). Hvorfor er uvisheden et alvorligt slag i livet hos de unge pårørende? Hvad er det, der rystes af uvisheden? Den er jo for så vidt et principielt livsvilkår for os alle (ingen af os ved, hvor længe vi eller vores nærmeste lever). Når livet er præget af uvished om forælderens overlevelse, så argumenterer jeg i denne artikel, at de unge pårørende befinder sig i en anden social udviklingssituation end deres jævnaldrende, fordi de eksistentielt, praktisk, emotionelt og ikke mindst socialt er påvirkede af at have alvorlig sygdom og truslen om forældertab inde på livet. I det følgende vil jeg begrunde denne påstand og tilbyde en række analytiske fund og begreber, der beskriver de centrale aspekter ved ungelivet som pårørende til en syg forælder. Det er ærindet med artiklen, at fremhæve hvad de unge har til fælles som følge af alle at have en forælder med en livstruende sygdom, hvorfor deres øvrige og særlige livsomstændigheder, familieformer, relationer og unikke personlige historie er udeladt fra analysen. 


\section{Undersøgelsens empiri og afgrænsning}

Undersøgelsens empiri består i 33 semi-strukturerede kvalitative interviews foretaget i årene 2008-2013 med 13-19 årige der har alvorligt somatisk syge forældre, hvoraf kun syv af deltagerne er drenge. De få drenge skyldes bl.a. den primære rekruttering gennem Børn, Unge og Sorg som har flest piger i brugergruppen. Flest af de unges forældre er ramt af lidelser, man typisk dør som følge af, primært cancer eller lidelser af en episodisk eller akut art, f.eks. svigtende indre organer. Langt de fleste forældre er døende eller i gang med behandlinger, som de unge ikke tør håbe på stor effekt af. 26 af interviewpersonerne er rekrutteret igennem Børn, Unge og Sorgs rådgivningstilbud i København, Odense og Århus, og 10 andre har selv henvendt sig via facebook og andre kanaler. Blandt de 10, som selv henvendte sig (hvoraf flere ikke modtog professionel hjælp), var nogle af de mest ulykkelige og belastede tilfælde. Det er således sandsynligt, at de unge i netop dette materiale udgør en udpræget belastet gruppe blandt de unge pårørende, hvorfor undersøgelsens resultater særligt må tænkes at gælde for de unge med døende eller meget alvorligt syge forældre, og at de ikke uden videre kan overføres til pårørende, hvis forældres liv ikke er truet. Alle i undersøgelsen er blevet spurgt til deres inddragelse i sygdommen (praktisk/emotionelt), og deres vurdering af sygdommens alvor, deres dagligliv og trivsel (i skole og hjemme), og om de synes, deres relationer til andre og syn på dem selv er ændret undervejs.

Undersøgelsen har udforsket de unges livssituation generelt, i et forsøg på at få viden om, ikke bare relationen til den syge forælder, men også hvordan sygdommen og situationen påvirker eller indvirker på de unges liv i skolen, med de jævnaldrende og i fritiden. Dette helhedsfokus afspejler analysens sigte, som er at beskrive, hvad de unge pårørende har til fælles, forstået i lyset af kulturhistorisk udviklingspsykologi og indsigter fra eksistensfænomenologien.

\section{Kulturhistorisk udviklingsteori og begreber}

Den kulturhistoriske udviklingspsykologi lægger op til en afdækning af de udviklingsimplikationer en bestemt livsituation afstedkommer, med begreber om motiver, projekter og den sociale udviklingssituation (Hedegaard 2012). I denne tradition betragtes børn og unges udvikling som en helhed, der studeres gennem analyser af de unges deltagelse i centrale aktiviteter og relationer, tænkt i sammenhæng med de historisk udviklede praksisser og institutionelle/samfundsmæssige 
funktioner og værdier deltagelsen er indlejret i (ibid.). Her vil man konkret analysere, hvilke muligheder den unge, i dette tilfælde med en alvorligt syg/døende forælder, tilbydes for deltagelse, og hvilke motiver og kompetencer de tilskyndes til at udvikle: ud fra en normativ og funktionel vurdering. Der lægges særligt vægt på, hvilke motiver de unge har og udvikler, fordi motiverne angiver den enkeltes engagerede virksomhed og åbenhed i forhold til aktiviteter og projekter, med betydning for hvor den enkelte er på vej hen set i lyset af de udviklingsopgaver, den enkelte stilles overfor. Der er således et fokus på den unges her-og-nu situation, men også på hvilke udviklingsimplikationer sygdomssituationen indebærer på sigt for den unge. Det er sammenhængen mellem de samfundsmæssige og institutionelle forventninger, værdier, krav, og personens mere eller mindre konfliktfulde og oplevede position i forhold til disse som begrebet om "den sociale udviklingssituation" henviser til (Boszhovitz 2009).

\section{Eksistensfænomenologisk analysestrategi}

Den eksistensfænomenologisk inspirerede del af analysen afdækker spørgsmål der vedrører det personlige oplevelsesmæssige aspekt ved en situation set fra et første persons perspektiv (Feilberg 2012). Undersøgelsen af det personlige perspektiv, den andens livsverden, kan kun blive tilnærmet og involverer derfor nødvendigvis fortolkning (Stanghellini 2016). For at tilnærme mig den unges første person perspektiv har jeg stillet mig selv følgende spørgsmål i analysen af materialet: Hvad er det for en måde at være i verden på, der beskrives? Og hvor i består forandringerne/forskellene fra livet før sygdommen? På den måde kan jeg afdække de mere eksistentielt fundamentale implikationer af livet som pårørende til en syg forælder, så tæt på jeg kan komme. Jeg har endvidere benyttet en kontrasterende analytisk strategi som kaldes for forestillet variation, som er velegnet til at fremanalysere de særlige kendetegn ved et studeret fænomen (Finlay 2014). I dette tilfælde foretages kontrasteringen til livet blandt unge med raske forældre som den forskelssætning, der får det særlige ved fænomenet ung med en syg forælder til at træde frem. Her trækker jeg både på udviklingspsykologien, nyere dansk ungdomsforskning og eksistensfænomenologien. Heidegger beskriver hvordan døden rammer Man'et, det vil sige naboen og de anonyme andre (Heidegger 2014). Vi lever i almindelighed ud fra den forestilling, at døden ikke vedkommer os personligt - og derfor kan vi lykkes med ikke at forholde os til vores egen ultimative endeligt på en emotionelt forpligtet måde. I stedet afbødes dødens virkelige 
rædsel med snakkens tildækning, og det som kun er vedkommende for nogle (uheldige) andre (ibid.). Det konkrete møde både med død og livstruende sygdom kaster os ud af denne betryggende gennemsnitlige væren og tilbage på os selv, hvilket bevirker, at vi pludselig føler os uden for det fælles, alene og udsat. Denne pointe illustreres helt gennemgående i de unges egne udsagn, når de forholder sig til den gennemsnitlige norm for ungdomsliv, som de ikke længere føler, de kan identificere sig med på samme måde længere.

\section{Forælder sygdom fra et udviklingsperspektiv}

Hvordan børn forstår og forholder sig til døden, alvorlig sygdom og forestående tab i forskellige aldre, og sammenlignet med voksne, i forskellige samfund, kulturer og situationer er fortsat omdiskuteret (Harris 2011; Koocher 1981; Saldinger et al. 1999). Det er dog et gennemgående fund at småbørn forholder sig til og forstår døden anderledes end store børn og teenagere (f.eks. er det først fra omkring 10 års alderen, at døden ses som resultat af et irreversibelt sammenbrud af livsvigtige kropsfunktioner). Men hvordan disse forskellige forståelser påvirker børnenes frygt, trivsel, bekymringer og håb er mere uklart (Slaugther and Griffiths 2007). Det er måske også mere relevant, at småbørn generelt er helt og holdent bundet til deres umiddelbare og konkrete omverden fra et her-og-nu perspektiv med kortere fremtidshorisonter end ældre børn og voksne (Garbarino et al. 1997, 304). Teenagere tænker sig selv og andre længere frem i tiden og har derfor en større tendens til at bekymre sig om dystre fremtidsudsigter, hvorfor teenage-alderen også fremhæves som en særlig sårbar tid at opleve alvorlig forælder sygdom i, fordi: "sammenlignet med yngre børn, har teenageren større kognitive og empatiske kapaciteter, hvilket giver anledning til større fokus på de forestående tab, og forælderens fysiske og emotionelle smerte" (Christ et al. 1994, 604). Uden at afvise at der er en sådan forbindelse mellem udviklingen generelt og pårørende-situationen specifikt- så er det værd at bemærke, at de kapaciteter, som afstedkommer større sårbarhed i én situation, kan vise sig at være beskyttende i en anden situation og vice versa (Schousboe 2000, 160). I familier hvor sygdommen for alvor virker forstyrrende ind på de relationelle samspil, forældrenes overskud, stemningen i hjemmet osv., kan det meget vel være at de yngste børn i familien påvirkes endnu mere end de ældre børn, fordi de netop er bundet til det konkrete her og nu's præmisser, og er mere afhængige af deres forældres overskud til deltagelse i aktiviteterne omkring dem. Mindre børn kan ikke selv transportere sig rundt til fritidsaktiviteter eller 
til venner, og være dér når det bliver for tungt at være derhjemme. Så i stedet for at diskutere i hvilken aldersperiode det er værst at leve med forælder-sygdom på et generelt niveau, foreslår jeg at anlægge det perspektiv, at alvorlig forælder-sygdom altid vil indvirke forskelligt i forskellige børns særlige liv. Alle børns unikke tilværelse er samtidig en tilværelse, som indebærer barnets sociale udviklingssituation under den kritiske overgang, som sygdomstiden udgør (Hedegaard 2012). Når man anlægger et sådan helhedsperspektiv på studiet af børn som pårørende, så er det både det individuelle niveau (barnets unikke vurderinger, motiver og engagementer) såvel som den samfundsmæssige og institutionelle organisering omkring barnet, som barnet lever indenfor rammerne af (f.eks. i familien og skolen), der påvirkes af sygdommen som livsomstændighed. Begge dele (det specifikke og det almene) må inddrages for at opnå et helhedsperspektiv på udviklingen, og må teoretiseres i sin helhed.

\section{Sammenflettede livstider}

Jeg foreslår, at alle centrale hengivenhedsrelationer har en forventet fremtidshorisont, og at forventningen knytter sig til livet ikke bare som socialt forbundet her-og-nu, men som organiseret på baggrund af en forventning om sammenflettede livstider (mellem os selv og vores nærmeste). Fremtiden og forventningshorisonten står derfor helt centralt som grundlag for, eller præmis for, relationerne til vores nærmeste. Når en person rammes af alvorlig sygdom, så griber det forstyrrende ind i denne før-refleksive og u-udtalte forventning: AT vi har en fremtid sammen. Det er en tid, vi regner med - og vi regner med den i et omfang, der gør, at den sammenflettede livstid bliver en fungerende præmis, for hvordan vi prioriterer mellem muligheder, tilskriver begivenheder betydning og kort sagt organiserer vores daglige livsførelse (Dreier 2001). Vi ved jo godt, at der kan ske forfærdelige ting, men der er stor forskel på, når denne usandsynlige potentialitet går fra at være rent hypotetisk til at være en virkelig risiko i et virkeligt levet pårørendeliv (med alle de praktiske, emotionelle og stemningsmæssige følger af det). Det betyder at et evt. forestående tab bliver en emotionelt forpligtet mulighed, som ryster den forudgående og naturlige tillid til, at vi har hinanden på ubestemt tid, og at vores liv vil forme sig nogenlunde sådan, som de kulturelt medierede metaforer om livscykliske begivenheder foreslår (Becker 1994). Det betyder f.eks. at forældre regner med at have deres børn livet $\mathrm{ud}$, og teenagere forventer først at miste deres forældre langt, langt ude i fremtiden, når de selv er blevet voksne. Fænomenolo- 
gisk set fungerer disse forventningsbilleder som bagtæppe, som uudtalt forudsætning, der sætter os i stand til at sige farvel om morgenen, passe vores gøremål, lægge planer og engagere os i egne projekter. Alvorlig sygdom hos en forælder er således en uventet forstyrrelse af forestillingen om sammenflettede livstider i teenage-livet, som giver anledning til at den sædvanlige laden-som-om-vished bliver ledsaget af, eller helt overtaget af, en hvad-nu-hvis-uvished (Winther-Lindqvist 2016a).

\section{Teenageres sociale udviklingssituation}

I Danmark lever de fleste teenagere en stor del af deres hverdagsliv uden for hjemmet: i skolen, til fritidsaktiviteter og sammen med jævnaldrende (kærester og venner). For de fleste vil udviklingen involvere en stadig større praktisk uafhængighed af hjemmet og samtidig et stadigt stigende engagement i egne projekter og selvstændige relationer. De unges egne projekter og engagementer handler om at udvide og individuelt tone deres livsbane i forhold til både at dygtiggøre sig og nyde, vælge til og vælge fra i ungdomslivets aktiviteter (Illeris et al. 2009). De unges forældre vil også typisk understøtte disse engagementer i form af økonomisk forsørgelse, praktisk hjælp osv. og således tilgodese de unges muligheder for at lykkedes uden for hjemmet. Det betyder, at de fleste teenagere tænker (mest) på sig selv, forstået positivt som, at de har travlt med at tage sig af sig selv, fokusere på sig selv og deres egne relationer og projekter (Kroger 2000). Men det gælder vel at mærke kun for de, som ikke har gode grunde til andet som f.eks. at bekymre sig om en forælder, der er blevet alvorlig syg. Ved alvorlig sygdom i familien (eller ved andre alvorlige omstændigheder) forsvinder eller mindskes de karakteristika beskrevet ovenfor, og bliver i stedet for privilegier de unge pårørende kan se andre unge har. Motiverne rettet mod eget ungeliv forsvinder ikke hos de pårørende, men ledsages af nye og konkurrerende motiver, der gælder familiens ve og vel. Det er netop disse forandringer, der er baggrunden for min påstand, om at de unge pårørende er $\mathrm{i}$ en anden social udviklingssituation end deres jævnaldrende med raske forældre. De unge med en syg forælder får ofte flere og mere omfattende huslige pligter og tager del i familiens opretholdelse på en mere aktiv måde, som understreger, at deres situation både praktisk og emotionelt er anderledes fra de jævnaldrendes situation (Ireland \& Pakenham 2010). De unges trivsel afhænger i høj grad af hvilken støtte de får gennem familien og det øvrige sociale netværk, men det er desværre ofte den støtte og relationerne både i familien og med de 
jævnaldrende, der udfordres under sygdom (Engelbrekt 2005, Nielsen \& WintherLindqvist, 2018).

I oversigten nedenfor har jeg opsummeret de typiske forskelle på teenagere, som er pårørende og teenagere med raske forældre. Oversigten udpeger overordnede tendenser, som de tales frem af de unge pårørende og som de bekræftes $\mathrm{i}$ ungdomsforskningen. Det betyder også at tendenserne kan træde mere eller mindre entydigt frem i den enkelte teenagers tilværelse.

Forskelle på motiver i den sociale udviklingssituation

\begin{tabular}{|l|l|}
\hline Teenager med raske forældre & Teenager med en syg forælder \\
\hline Ledende motiv: Ungelivet & Ledende motiv: Familielivet \\
\hline Identifikation med jævnaldrende & $\begin{array}{l}\text { Har svært ved at identificere sig med } \\
\text { jævnaldrende }\end{array}$ \\
\hline $\begin{array}{l}\text { Deler følelser med jævnaldrende - op- } \\
\text { bygger intimitet }\end{array}$ & $\begin{array}{l}\text { Skjuler følelser fra jævnaldrende - op- } \\
\text { bygger privat væren/facade }\end{array}$ \\
\hline Tænker (mest) på egne behov & Tænker (mest) på familiens behov \\
\hline Udvikler egne projekter & Sætter egne projekter på hold \\
\hline
\end{tabular}

Det er de opsummerede pointer i modellen, som er de overordnede forskelssættende træk mellem unge der er pårørende og unge med raske forældre. Flere af problematikkerne er almene, f.eks. kender de fleste formodentlig til at være splittet mellem flere motiver, men dilemmaet får en særlig præsent intensitet i ungelivet som pårørende til alvorlig sygdom, netop fordi fremtiden med forælderen er uvis, og de sammenflettede livstider er truet. Nedenfor begrunder jeg, hvorfor uvisheden er det centrale set fra det personlige første persons perspektiv, hvorefter jeg præsenterer nogle af de udbredte følger af situationen, og hvordan de typisk håndteres af de unge.

\section{Fra et tredje persons perspektiv til et første persons perspektiv på pårørende situationen}

Psykiateren John Rolland's (1999) sygdomsmodel kan fungere som deskriptivt rammeværk til at forstå progressive lidelsers typiske forløb og udfordringer i sygdomsramte familier. 


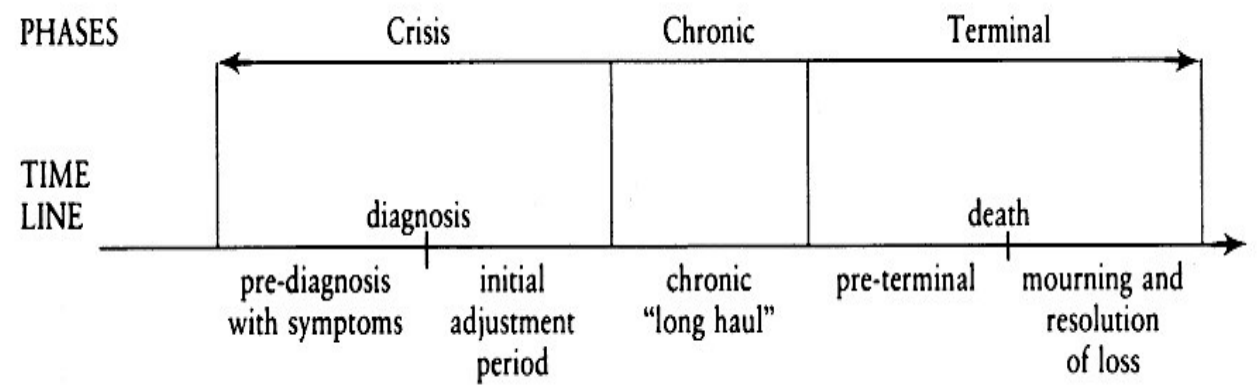

Rolland foreslår at processen opdeles i overgange og særlige begivenheder, som justeringerne organiseres omkring. I flg. Rolland efterfølges den første krise-tid af en ny kronisk fase, hvor familiens medlemmer, sammen og hver for sig, vænner sig til de implikationer, indskrænkninger (økonomisk og eller aktivitetsmæssigt) som sygdommen afstedkommer, samtidig med at der alligevel hele tiden er forandringer i form af forværring eller forbedringer i disse. Den kroniske fase kan være særligt udmattende og langstrakt (selvom det ikke visuelt fremgår af modellen), hvorfor Rolland også kalder denne fase "det lange træk". I dag, vil jeg argumentere for, har også den præ-terminale fase sit eget "lange træk", hvor døden er forventelig og håbet om en kur er opgivet, men forælderen bliver ved at (over)leve. Rolland's fase model illustrerer et kanoniseret forløb for fatale progressive lidelser, og den identificerer typiske problemstillinger til brug f.eks. i psyko-edukativ sammenhæng. Men den er en tredje persons model, som ser på sygdommen udefra. Med et eksistensfænomenologisk afsæt bliver det tydeligt, at modellen ikke afspejler det personlige første persons perspektiv, som man analytisk kan adressere gennem spørgsmålet: Hvad vil det sige at være i verden på den måde? De unge pårørende i undersøgelsen aner jo ikke, hvor de er henne i processen lige nu, eller hvor udviklingen peger hen, fordi de ikke har et udefra-blik på et overstået forløb, men står midt i deres liv med hinanden- mens det skrider frem, og det står åbent om deres forælder vil blive ved at være syg, dø, eller måske blive rask.

\section{Uvished som organiserende princip}

At leve med truslen om tab bliver en del af teenagerens livsverden og eksistentielle horisont, hvilket giver anledning til en række nye dilemmaer. 17-årige Mia, der bor alene sammen med sin mor, er i tvivl om hvorvidt hun skal tage ud at rejse som planlagt med sine veninder i tre måneder, set i lyset af morens fremskredne 
sygdom. Hun har mange overvejelser som alle cirkler omkring uvisheden om, hvornår hendes mor skal $\mathrm{d} \varnothing-$ men hun reflekterer også på forskellen på sin egen og venindernes situation: "De andres mødre kunne jo også dø mens vi var afsted...jeg mener, man kan jo aldrig vide hoad der kan ske. Det er jo bare ikke noget de tænker over, vel?" Citatet indrammer tydeligt, hvad jeg mener med, at teenagerens horisont globalt set ændrer sig i mødet med truslen om forældretab, og at uvisheden gælder globalt, som organiserende princip. Jeg har foreslået en model til illustration af nogle af de dynamikker, uvisheden synes at medføre for de unge i undersøgelsen (Winther-Lindqvist, 2014)

\section{Uvished som organiserende princip}

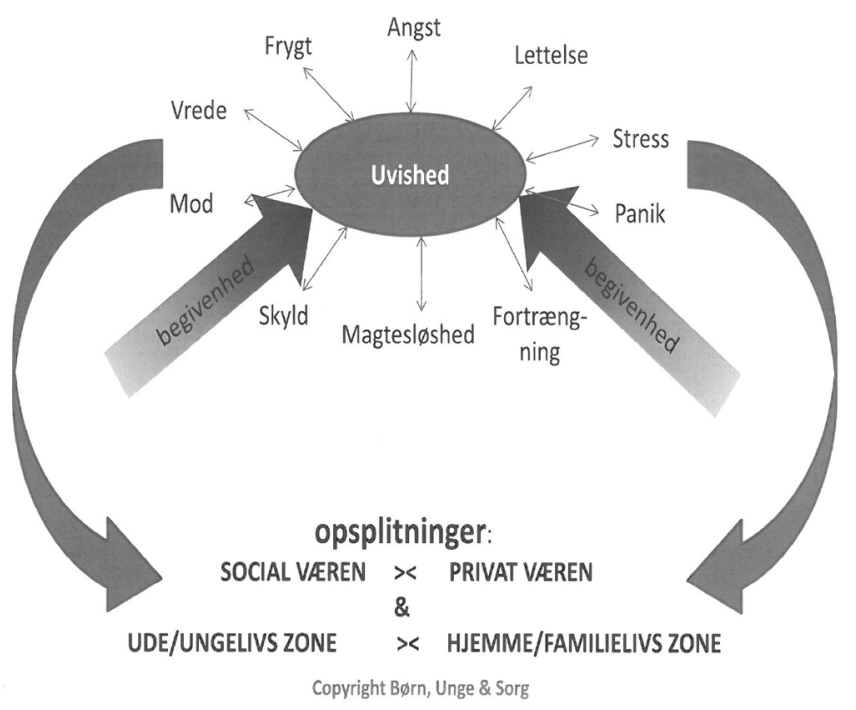

I modellen om uvished som organiserende princip fremgår det, at uvisheden hele tiden står centralt for, hvad de unge orienterer sig efter, og for hvordan de har det. Ved sygdomme med dårlige prognoser og i tilfælde af recidiv er truslen om forælder-tab større end i tilfælde med gode prognoser. Men der er ikke nogen forudsigelig sammenhæng mellem sygdommens prognose og den psykologiske virkelighed. Nogle unge frygter at miste deres forælder, selvom der ikke er medicinsk belæg for så stor bekymring, og omvendt tror andre ikke på, at det virkelig kan være så alvorligt (og indser først meget sent eller helt til sidst at deres forælder er døende). Sygdomssituationen medfører, at mange videns- og informationskilder melder sig og også næres af hvad de unge selv håber, tror, ser og mærker. 
I fænomenologien skelner man mellem kroppen som subjektivt liv og kroppen som legeme (Zahavi 2013). Det syge legeme er på alle måder mystisk for de unge: "Hvordan kan min stærke far være så alvorligt syg - det havde jeg så svært ved at tro på" (Emilie 15 år) eller omvendt, "hvordan kan det være, at det ikke er mere farligt, når min mor ingenting kan og ligger $i$ sengen på grund af så stxrke smerter, hver dag... Jeg mener der er vel grænser for hvor meget kroppen kan tåle" (Markus 14 år). Der er ikke altid kongruens mellem forælderens tilsyneladende tilstand og de prognostiske beskeder, de unge får. De fleste unge i undersøgelsen med en forælder, der har en fatal fremskreden lidelse, når et punkt, hvor det dødelige udfald til sidst står klart for dem: "Da jeg kom hjem fra efterskolen, kunne jeg jo godt se... ok... Han er virkelig blevet meget dårligere og sådan helt svag. Han kommer ikke til at klare det her!" (Ina 16 år). Undervejs og i sygdommens tidligere faser er det uvisheden og håbet om at situationen kan vende (ved en kur, eller i det mindste en virksom behandling), der er mest fremtrædende ${ }^{1}$.

At uvisheden bliver et organiserende princip betyder blandt andet, at de unge "tvinges" til at udvikle strategier for at håndtere deres dagligdag med mange forpligtelser både ude og hjemme. Det gør de blandt andet ved at skabe sig frirum, der sikrer dem hvilepauser, og derudover skaber de typisk nogle opsplitninger der giver dem en fornemmelse af kontrol med, hvornår de konfronteres med sygdommen, og hvem de deler deres følelser og oplevelser omkring sygdommen med. Jeg har kaldt disse håndteringsstrategier for henholdsvis opsplitninger i mellem privat og social væren, og opsplitninger mellem hjemme-familieliv og ude-ungeliv.

\section{Frirum og hvilepauser}

Uvisheden giver anledning til at forme forskellige former for håb, opleve store emotionelle svingninger, og ind i mellem være helt udmattet over situationen, men de unge pårørendes liv fortsætter også med at involvere helt almindelige hverdagslivs krav og problematikker. De unge har skolen/ungdomsuddannelsen, lektierne, vennerne og andre engagementer som fylder for dem. Analysen viser, at de unge føler, det hober sig op for dem, fordi sygdommens vilkår netop kommer oven i alle de andre ting, der optager dem, og som de kæmper med. De unge beskriver et hverdagsliv, der balancerer på kanten af det mulige, og netop derfor er det afgørende at have ventiler og frirum fra bekymringer og dilemmaer. De unge forsøger at skabe rum for sig selv, hvor bekymringer og konfrontationen med sygdommen ikke fylder så meget. Jeg kalder disse frirum, der giver mulighed for hvi- 
lepauser. For nogle udgør skolen og den faglige fordybelse i lektielæsning f.eks. sådan en hvilepause. For andre kan det næsten ikke lade sig gøre at koncentrere sig om noget fagligt, i stedet fungerer deltidsjobbet eller fritidslivet (rideklubben, håndbold, etc.), samvær med venner, alene-tid på værelset, computerspil, løbeture etc. som sådanne. Behovet for frirum er udtalt, som en lettelse, som et sted at kunne være normal og sig selv. "På rideskolen er der ingen, der ved at min mor er syg og det er faktisk en stor lettelse, for så kan jeg bare være mig selv, som jeg var inden min mor blev syg" (Emma 16 år). Der er et sammenfald mellem de unge, som beskriver en hverdag uden frirum, og de som beskriver sig selv som mest stressede og udkørte: Louise, der er 16 og har en syg mor, forklarer: "Når jeg er derhjemme tænker jeg på vennerne, og hoad de nu laver - og når jeg er ude med dem, så tænker jeg på, at jeg skulle se at komme hjem...Så jeg har faktisk aldrig ro noget sted".

\section{Opsplitninger i mellem privat og social væren: Hjemme}

De unge pårørende har en tendens til at lave skarpe skel mellem en privat og social væren, dvs. der er tanker og følelser, de ikke deler med andre, hvilket også er et fund i andre undersøgelser. De unge er ofte mere påvirket og mere triste, end deres forældre vurderer det (Grabiak et al. 2007). Det skyldes formodentlig at de unge pårørende gør sig store anstrengelser for at skjule hvordan de faktisk har det (Maynard et al. 2013). Det er et udbredt fænomen blandt pårørende og "young carers", også i familier med psykisk sygdom, at de unge ikke gør opmærksom på egne behov og i stedet tænker mest på forælderens velbefindende (Trondsen 2011). Ofte bliver det også knyttet sammen med de rolleskred, der kan ske i sygdomsramte familier, hvor børnene påtager sig eller tildeles en større omsorgsgivende funktion både praktisk og emotionelt, end det normalt er tilfældet i den pågældende kultur (også kaldet "parentification of children") (Dyregrov 2012). Heldigvis lykkes det for mange at fastholde almindelig omsorg, åbenhed og medleven i hinandens liv, men alle synes at det er ekstra krævende i nogle perioder. Som Rikke på 19 forklarer: "nogen gange er det bare som om, at vi alle sammen har brug for mere af hinanden - men vi har også alle sammen mindre at give af. På en måde kæmper vi bare for at blive ved at vare os selv."

Det at vise omsorg for hinanden, tage hensyn, og beskytte hinanden bliver en udfordring, som ind i mellem svigter, og rigtig mange unge skjuler deres skuf- 
felser eller følelser af svigt, fordi de ikke vil belemre den allerede pressede familie yderligere. At skjule følelser er i det hele taget udbredt, også i forhold til følelser vedrørende sygdommens alvor. Ina på 16 år siger om sin frygt for at miste sin mor, at der er noget de ikke kan dele: "Jeg kan bare ikke tale om min frygt for at miste hende, for det er som om at jeg så har opgivet håbet". For nogle opleves det som en emotionel distancering til familien, og selvom de fleste taler om, at de godt kan forstå, at det ikke er deres behov, der står øverst på dagsordenen, så er det alligevel hårdt ikke at udtrykke sine behov og ofte savne at få dem indfriet.

\section{Opsplitninger i mellem privat og social væren: Ude}

I forhold til de jævnaldrende skelner de unge også skarpt mellem det, som holdes privat, og det, som deles med andre. De unge pårørende holder sig tilbage fra at vise, hvordan de virkelig har det af frygt for at trætte deres relationer og af frygt for at skræmme deres venner væk. Nogle taler om det som en maske, de tager på, eller de omtaler sig selv som én med en facade over for andre: "I skolen er jeg bare glade Morten, så tager jeg min glade maske på" (Morten 15 år, med en syg mor). Andre viser kun, hvordan de har det på afmålte måder og tidspunkter. Ligesom andre har lært sig måder at styre humøret på. Katrina på 16 med en syg far, fortæller: "Jeg kan godt være helt flad og trist og slet ikke have lyst til at gå til den fest. Men så har jeg jo lovet at komme, og så tvinger jeg ligesom mig selv til at tage derover og lader som om jeg er glad. Og rigtig tit, så ved jeg også, at der ikke går ret lang tid, så bliver jeg faktisk i godt humør". Alle unge er optaget af en vis selekteret selv-fremstilling (ingen fortæller alle alt). Men de fleste unge er også opsatte på at opbygge og nyde intimiteten ved faktisk at dele deres tanker og sindsstilstande med gode venner. Det at holde tanker og følelser tilbage for sine venner, får en tvungen tyngde for de unge pårørende, der efterlader dem med en større følelse af isolation eller anderledeshed. Selvom opsplitningen både over for venner og familie er ambivalent og krævende, så minimerer det alligevel nogle konfrontationer, som fra de unges synspunkt opleves som værre. De foretrækker at undlade at bekymre forældrene for meget eller at trætte vennerne og øge risikoen for at skubbe dem fra sig. 


\section{Opsplitninger mellem familieliv og ungeliv}

Den anden typiske opsplitning vedrører det, jeg kalder, splittet mellem familielivszonen og ungelivs-zonen. Det opleves som vanskeligt at forene de to livsarenaer, og de fleste vælger helt at lade være i perioder. Som 16 årige Peter forklarer: "Der er noget jeg har tænkt over, i forhold til at prøve at få mit liv op at køre igen, at det der med at få mine to verdener kombineret. Mit liv med vennerne og mit liv med en syg forælder. Man kan bare ikke rigtig bringe sin syge far ind $i$ sit liv med vennerne, for de forstår bare ikke, hoad det handler om, og ja...jeg har bare ikke lyst til at have vennerne hjem her". Eller som Ida på 17, hvis far nu sidder i rullestol, forklarer: "Jeg har ikke mine veninder med hjem mere. Mit hjem er jo blevet sådan et handicap hjem nu med slisker og hejse og rullestol og sprøjter... Nej det har jeg bare ikke lyst til". At forsøge at holde sine verdener adskilt giver en følelse af kontrol med, hvor sygdommen fylder (derhjemme), og hvor den ikke gør (i ungelivets zone). Samtidig kan de unge, gennem opsplitingen, opnå en oplevelse af at være normale og mere ligesom deres jævnaldrende, som de er begyndt at føle sig forskellige fra. Kun få, i denne undersøgelse, lykkedes godt, med at skabe broer mellem deres livszoner og involvere kammerater og venner i livet derhjemme direkte. De fleste foretrækker at holde tingene adskilt, og så håndtere udfordringerne når livszonerne alligevel mødes.

\section{Distancering fra de jævnaldrende}

Alle de medvirkende i undersøgelsen beskriver følelsesudsving som en ny drænende virkelighed i deres liv. Der er gode perioder hvor håbet og optimismen fylder, og så er der perioder hvor tvivl, angst eller udmattelse tager over, men for nogle er de hele registret igennem på en dag. De emotionelle svingninger knytter sig ikke eksklusivt til begivenheder og udvikling i sygdommens forløb i nogen snæver forstand, som Eva på 15, der har en syg far, forklarer: “Jeg bliver faktisk tit mest deprimeret og ked af det, når der sker alle mulige andre ting. Hvis jeg f.eks. kommer op at skændes med min veninde, eller hvis jeg synes at en af mine lærere er totalt unfair. Så er det som om, det bare er dråben, at jeg bare ikke kan tage det mere". Øget irritabilitet og aggressive udfald er også almindelige. Ida på 17 forklarer om sig selv: "Jeg har altid været øhmm temperamentsfuld og sådan hidsig. Men her de her år, der har det virkelig været svært for mig at styre det. Jeg bliver bare så arrig og rasende, og har rigtig svært ved ligesom at falde ned igen bagefter". Mange taler om et sænket stemningsleje grundet den nye alvor og uvisheden om fremtiden, som sygdommen hele tiden afstedkom- 
mer. Jakob på 13 med en syg far siger: "Det er som om, der er en lille sky, der bare regner lidt på mig hele tiden". Humør-udsving og sænket stemningsleje udgør en af de største udfordringer i forhold til relationerne med de jævnaldrende og vennerne. Stine på 16 siger: "Jeg skifter hele tiden, og tit er jeg bare sur...men tit er jeg også bare bekymret, og så ud af det blå får jeg lyst til at græde...og så andre gange er jeg bare norma, og glad og glemmer det hele...Det er ret forvirrende". De udfordringer, som ungelivet med en alvorligt syg forælder indebærer, har de jævnaldrende generelt svært ved at forstå og relatere til. De pårørende føler sig anderledes, fordi deres venner og kammerater har svært ved at forstå dem. Forskellene i art, omfang og dybde på de problemer, der fylder i de unges liv, gør det vanskeligt for de unge pårørende rigtig at spejle sig i deres jævnaldrendes livssituation. Sommetider med et misundeligt eller bittert twist - andre gange med et perspektiv og nogle problematikker, der bare helt nøgternt er af en anden orden, end det de jævnaldrende går op i. Som Emilia på 15 siger: "Jeg kan da godt få det sådan nogle gange..altså hvorfor får du dig ikke et rigtigt problem? Du sidder og tuder nærmest over, at din kæreste ikke har svaret dig på sms indenfor tre timer, og jeg altså...hvis ikke min far kan tåle sin nye medicin, ja så dør han...det er ligesom ret langt fra hinanden". Selvom de unge pårørende kan sige til sig selv, at deres venners problemer stadig er lige så relevante og vigtige for dem, som før - så ændrer det ikke på at deres egne problemer er af en anden orden og alvor, hvilket uanset om venskabet holder, ofte giver dem en udpræget oplevelse af at være anderledes, som Ida på 17 beskriver det: "Jeg føler bare, at jeg er i min egen kasse - $i$ min kasse er der sygdom og alt muligt - og de er i deres kasse med venner, drenge og fester og alt det der". Mange oplever venskabsbrud enten som resultat af direkte konflikter, der knytter sig til den pårørendes situation, eller indirekte som f.eks. følge af længerevarende tilbagetrækning fra det sociale liv. De unge pårørende er stærkt påvirkede af disse brud og konflikter med venner og føler sig skuffede, afviste og misforståede. Igen er der tale om en almen problematik i teenagelivet, men det får et særligt præg af afmægtighed og uretfærdighed hos de unge pårørende, som knytter bruddet og konflikten sammen med sygdomssituationen. Den marginaliserede sociale situation, de unge pårørende ofte føler sig i, enten fordi de har mistet deres venner eller føler sig anderledes og distancerede fra dem, kan vi med Heidegger genkende som at falde ud af Man'ets gennemsnitlige væren. Det teenageliv de unge pårørende kan se og forestiller sig, "de andre" unge har - er de ikke længere en naturlig del af. 


\section{Øget praktisk ansvar og huslige pligter}

De fleste familier med svær sygdom kommer i en situation hvor den unge (eksplicit eller implicit) er mere behøvet hjemme - $i$ hvert fald i perioder. Ofte er det $i$ form af at hjælpe mere med at løse familiens praktiske opgaver og/eller i forhold til at støtte den raske forælder/den syge forælder og evt. yngre søskende. Her er stor forskel på behovet i de forskellige familier (er der f.eks. en rask forælder, som kan tage sig af mere, når den syge forælder er for udmattet eller smertepræget). De fleste unge oplever det som et nødvendigt onde, og nogle har selv et ønske om at hjælpe med det, de nu kan. Omvendt giver det anledning til konflikt særligt søskende imellem (om hvem der gør hvad, og hvem der ikke gør nok). Selve sygdommens indvirkning på forælderen, og bestemte tidspunkter i sygdomsforløbet spiller også ind på hvor meget de unge er hjemme, og hvilke pligter de får. De unge tilskyndes på den måde til en større ansvarsfølelse over for familien, end de ser det hos deres jævnaldrende, samtidig med at de ikke tager til ligeså mange fester og sociale arrangementer. I nogle henseender ligner det et hverdagsliv, vi snarere genkender fra unge voksnes liv end fra teenageres, og flere af de pårørende føler sig også som "flere år foran". Rigtig mange af de pårørende trækker sig derfor mere tilbage fra unge- og vennelivet udenfor hjemmet - både fordi livet med de jævnaldrende bliver mere kompliceret, og opleves som krævende - og fordi de samtidig også (ofte) er mere behøvet derhjemme til at hjælpe til med det huslige. Det at blive erfaren med at tage sig af huslige opgaver bidrager også til en følelse af at være mere moden end de andre. Som Morten på 15 fortæller: "Jeg blev ligesom nærmest 3 år xldre $i$ de tre uger min far var indlagt. Fordi min mor var ude hos ham på hospitalet næsten hele tiden, så hvis jeg ikke selv lavede aftensmad, så fik jeg bare ikke noget". Og særligt hos drengene, i denne undersøgelse, giver det også et forspring som kan virke imponerende på de jævnaldrende. Morten forklarer yderligere: "Jeg kan jo sagtens lave mad og selv lave noget lækkert - det synes mine venner er ret sejt."

\section{Tilsidesættelse af egne projekter}

Truslen om at forælderen kan dø af sin sygdom, og forpligtelserne derhjemme betyder at den unges motiver ændrer sig, på den måde at orienteringen efter og engagementet i ungelivet får selskab af og kommer i konkurrence med motivet om at tilbringe mere tid særligt med den syge forælder og i det hele taget stå mere til rådighed derhjemme. Det påvirker deres vurdering af, hvad der er vigtigst, 
og hvordan hverdagens opgaver prioriteres. For nogle betyder det en omfattende social tilbagetrækning fra engagementet i ungelivet, som ikke længere vurderes ligeså vigtigt og meningsfuldt for dem at deltage $i$, for andre betyder det snarere, at de forsøger at opretholde engagementerne både ude og hjemme, og de får som udfordring at få tid og energi til det hele. Det afstedkommer under alle omstændigheder, en række fremtrædende personlige dilemmaer og tvivlrådighed i forhold til hvordan og hvilke opgaver, der skal tilgodeses, og hvilke livsdomæner, som i perioder må nedprioriteres eller helt opgives. Det er ikke ualmindeligt at de pårørende opgiver fritidsinteresser eller må drosle ned på dem, ligesom deres muligheder for at passe skolen vanskeliggøres, sådan at de føler, de må vælge mellem f.eks. at gå ud med deres venner i weekenden eller prøve at indhente de lektier, de er kommet bagud med i ugens løb. På den måde opleves forælderens sygdom som et pres i form af nye opgaver og engagementer (i familien), der giver dem oplevelsen af, at det er svært eller umuligt at magte det hele, eller at der er nogle afsavn, de må affinde sig med, fordi situationen er som den er. Ina på 16 år siger: "Jeg kan bare slet ikke overskue andet end min far, som er så syg, og som hele tiden får det dårligere - og så min kæreste. Jeg kan ikke have andet $i$ mit hoved. Det fylder det hele". Eller som Emilie på 15 med en syg far siger: "Jeg har bare valgt at alt det der med fester og sådan noget. Det går jeg ikke til, fordi det er altså skolen, der er vigtigst for mig. Jeg vil bare gerne have gode karakterer og klare mig godt - og så må det andet altså... det kan jeg bare ikke overskue også". Den sociale tilbagetrækning og neddrosling på egne projekter er det mest almindelige i mit materiale, men der findes også de, som i stedet er ude så meget, det er muligt. Katinka på 14 siger: "Jeg tænker da nogle gange på, at jeg måske kommer til at fortryde, at jeg ikke var mere hjemme, og ikke var der mere for min far. Men jeg kan bare ikke holde ud at være hjemme. Jeg prøver nogle gange, men så... jeg kan bare ikke holde det ud-jeg bliver simpelthen sindssyg, hvis jeg skal være derhjemme". I mange familier opmuntrer forældrene til, at de unge ikke opgiver deres engagementer i ungelivet og egne projekter, som Camilla på 15 fortæller: "Mine forældre skubber også til mig. De vil jo heller ikke have, at jeg skal sidde herhjemme og gå glip af alt muligt. De ønsker jo ogsa for mig, at jeg bare skal have det sjovt og være ung". Bemærk det lille jo, som Camilla indskyder flere gange, der henviser til, at hendes tilskyndelse går i retning af at blive hjemme, så forældrene må forsikre hende om, at det er bedst, at hun også fortsat passer sine egne ting. 


\section{Mulige udviklingsimplikationer ved pårørende liv}

Opsamlende, så udgør de træk beskrevet i denne artikel ved pårørende-livet som ung en række implikationer for de unges udvikling. Det er centralt for unges trivsel at have fortrolige voksne - helst deres forældre - at kunne gå til, når de har vanskeligheder (Hansen et al 2015), ligesom stærke jævnaldrende fællesskaber og venskaber er altafgørende for et ungdomsliv i trivsel. Alvorlig somatisk sygdom hos en forælder kan på den måde påvirke de unges relationer både hjemme og ude og deres overskud til egne projekter på måder, der gør det svært for dem at klare hverdagen (Nielsen et al 2010, Leedham and Meyerowitz 1999). Livet med en alvorligt syg forælder ændrer de unges meningshorisont radikalt, uden det nødvendigvis behøver at ødelægge hele deres tilværelse. Intensiteten af uvisheden, belastningsgraden på forælderen, og måder at håndtere det sammen på varierer betydeligt. De unges motiver vedrørende ungelivet og egne projekter kommer dog typisk i konkurrence med et andet motiv om at være noget mere for familien: den syge og også den raske forælder og evt. yngre søskende. Det viser sig helt konkret i måden de unge pårørende deltager på i skolen, i forhold til prioriteringen af lektier, samvær med venner, at gå med til fester, hvilket igen ændrer deres sociale positioner i forhold til de jævnaldrende.

De strategier, som de unge håndterer uvisheden med, f.eks. opsplitninger mellem bestemte værensformer, er nok almene træk ved ungelivet, men de får en anden tyngde og alvor hos de unge pårørende, og de opleves som mere nødvendige, for at tilværelsen kan overskues under sygdom. Det samme gælder frirum og hvilepauserne, som alle har brug for - men som for de pårørende er langt vanskeligere at skabe. Det er væsentligt at fastholde, at forælder-sygdom påvirker børn og unges liv forskelligt, og at de fleste unge pårørende har det godt og fastholder at have håb for sig selv og for den syge forælder i familien. Det er blandt andet forskellige former for håb og de relationelle ressourcer omkring den unge (både hjemme og ude), der gør dem i stand til at håndtere uvisheden og sygdomsforløbet, på måder hvor de kan fastholde deltagelsen i ungdomslivet. Heldigvis har mange unge de ressourcer i deres liv, som er tilstrækkelige til, at de fortsætter med at deltage engageret i uddannelse, aktiviteter og jævnaldrende relationer. Men alvorlig sygdom er en livsomvæltende udviklingskrise for de pårørende, som Katrina på 16 år siger: "Det er min far der er syg, men sygdommen har vi alle sammen". Når sygdommen er potentielt dødelig, eller hvis sygdommen virker omsiggribende ind i familiens relationer, overskud og aktiviteter på indskrænkende måder - så er det gennemsyrende for den totale subjektive konfiguration inklusiv de øvrige sociale relationer 
og institutionelle positioner, som den unge altid er en del af (Rey 2012, 50-51). Det betyder, at de unge pårørende med alvorligt syge forældre befinder sig i en anden social udviklingssituation end deres jævnaldrende med raske forældre. De føler sig anderledes, fordi de faktisk er det.

Fokus i nærværende undersøgelse har været på at beskrive de særlige træk, der kendetegner livet som ung pårørende til en somatisk alvorligt syg forælder, og teoretisere over de oplevede udfordringer set fra et første persons perspektiv, suppleret med et øje for de udviklingsimplikationer disse medfører. Den eksistentielle modifikation, som mødet med sygdom og død medfører, ledsages imidlertid også ofte af en øget sensitivitet over de relationer og det netværk, som de unge har - og føler sig hjulpet af undervejs, både i og uden for familien. Som Stine på 16 siger om forholdet til sin mor: "Vi har altid været tæutte - der har på en måde altid kun været os...så på nogen måder er vores forhold faktisk blevet bedre nu, faktisk....Vi har også talt om det, fordi vi er blevet klar over... altså det kan jo slutte. Det vi har, kan forsvinde...og så har vi talt om, at det er der gode ting ved, altså! Hey- Det er dejligt at vi har hinanden (griner), og måske skulle vi være noget mere sammen og gøre nogle gode ting sammen".

\section{Noter}

${ }^{1}$ Håbets rolle og funktion for de unge pårørende er mere grundigt behandlet som selvstændigt tema i Winther-Lindqvist 2015, 2016b.

\section{Tak til}

Organisationen Børn, Unge og Sorg for at finansiere undersøgelsen og for at tilbyde unge pårørende og efterladte et professionelt og gratis tilbud om hjælp. Og tak til alle de unge som delte ud af deres oplevelser, mhp. at udbrede kendskabet til hvad ungeliv med en syg forældre indebærer.

\section{Referencer}

Becker, G. (1994). Metaphors in Disrupted Lives: Infertility and Cultural Constructions of Continuity. Medical Anthropology Quarterly, New Series 8 (4): 383-410.

Christ, G. H., K. Siegel, and D. Sperber. (1994). »Impact of Parental Terminal Cancer on Adolescents.« American Journal of Othopsychiatry 64:604-13 https://doi.org/10.1037/h0079569 
Christ, G. H.; Siegel, K. Christ, A. (2002). Adolescent grief »it never really hit me...until it actually happened«. JAMA, 11, vol. 288, no. 10. 1269-1278. https://doi.org/10.1001/ jama.288.10.1269

Dreier, O. (2001): Virksomhed - læring - deltagelse. Nordiske Udkast, nr.2. 39-58.

Dyregrov, K. (2012). Når foreldre har alvorlig kreftsygdom - eller dør av den. Haugland, B. S., Ytterhus, B., Dyregrov, K. (eds.). Barn som pårørende. Abtrakt Forlag. Pp. 44-66

Engelbrekt, P. (2005). Netværkets centrale betydning når forældre rammes af alvorlig sygdom. Omsorg- Nordisk tidsskrift for palliativ medisin, 22(4), 2005.pp 25-29.

Feilberg, C. (2012). Eksistentiel fænomenologi - betegnelsen, stilen og begrebet. In: K.D. Keller (red): Den menneskelige eksistens. S. 45-75. Aalborg Universitetsforlag.

Finlay, L. (2014). Engaging phenomenological analysis. Qualitative Research in Psychology, 11:2, 121-141. https://doi.org/10.1080/14780887.2013.807899

Garbarino, J., Kostelny, K. \& Barry, F (1997). Value transmission in an ecological context. High risk neigborhoods. In Parenting and children's internalization of values: a handbook of contemporary theory, J.E. Grusec \& L. Kutczynski (eds.). John Wiley \& Sons.

Grabiak, B. R.; Bender, C.M.; Puskar, K. R. (2007). The impact of parental cancer on the adolescent: an analysis of the literature. Psycho-Oncology, 16, pp. 127-137. https://doi. org/10.1002/pon.1083

Hedegaard, Mariane. (2012). The Dynamic Aspects in Children's Learning and Development, In Motives in children's development, M. Hedegaard, A. Edwards, and M. Fleer, (eds.). Cambridge: Cambridge University Press. 9-28.

Heidegger, Martin. (2014). Væren og Tid (Sein und Zeit). Klim.

Illeris, K., Katznelson, N., Nielsen, J.C., Simonsen, B. \& Sørensen, N.U. (2009): Ungdomsliv mellem individualisering og standardisering. Frederiksberg: Samfundslitteratur.

Ireland, M. \& Pakenham, K. (2010). Youth adjustment to parental illness or disability: the role of illness characteristics, caregiving and attachment. Psychology, Health \& Medicine, vol. 15. No.6. 632-645. https://doi.org/10.1080/13548506.2010.498891

Kroger, J. (2000). Identity Development. Adolescence through Adulthood. London: Sage.

Leedham, B. \& Meyerowitz, B. (1999). Responses to Parental Cancer. A Clinical Perspective. Journal of Clinical Psychology in Medical Settings 6 (4): 442-61. https://doi. org/10.1023/A:1026228000254

Maynard, A., Patterson, P.; McDonald, F. Stevens, G. (2013). What is helpful to adolescents who have a parent diagnosed with cancer? Journal of Psychosocial Oncology, 31:6, 675-697. https://doi.org/10.1080/07347332.2013.835021

Rey, Gonzales Fernando. (2012). Advancing on the Concept of Sense: Subjective Sense and Subjective Configurations in Human Development.« In Motives in Children's Development, Nielsen, J. C., N. U. Sørensen og N. M. Osmec (2010): Når det er svært at være ung i DK - unges trivsel og mistrivsel i tal. København: Center for Ungdomsforskning, Aarhus Universitet.

Nielsen, J. C. \& Winther-Lindqvist, D. (in press). Unge efterladte og pårørendes trivsel - og effekten af at tale om det! Psyke \& Logos, temanummer om Sorg, udkommer 2019

Rolland, J. S. (1999). Parental illness and disability: a family systems framework. Journal of family therapy (1999) 21: 242-266. https://doi.org/10.1111/1467-6427.00118

Schousboe, I. (2000). »Udviklingspsykologi og børn I virkeligheden. I, I nærheden - en antologi om børneperspektiver, L. Reimer, I. Schousboe, and P.Thorborg (red.), København: Hans Reitzels Forlag. 151-72. 
Slaughter, V., Griffiths, M. (2007) death understanding and fear of death in young children. Clin Child Psychol Psychiatry.Oct;12(4):525-35. https://doi.org/10.1177/1359104507080980

Stanghellini G. \& Aragona, M. (2016). Phenomenological Psychpathology: Toward a Person-Centered Hermeneutic Approach in the Clinical Encounter. In: Stanghellini Giovanni, Aragona, Massimiliano (eds.). An Experiential Approach to Psychopathology - what is it like to Suffer from Mental Disorders? Springer Press. P. 1-45 https://doi.org/10.1007/9783-319-29945-7_1

Trondsen, M. (2011). Living with a mentally ill parent: exploring adolescents' experiences and perspectives. Qualitative Health Research, 22(2) pp 174-188. https://doi. org/10.1177/1049732311420736

Winther-Lindqvist, D. (2014). »Uncertainty as Organizing Principle of Action. Teenagers Living with a Critically Ill Parent.« Journal of Illness, Crisis, and Loss 2 (22):95-115. https:// doi.org/10.2190/IL.22.2.b

Winther-Lindqvist, D. (2015). Uvished og håb - ung pårørende til en døende forælder. I Omsorg, nr. 4. 56-59

Winther-Lindqvist, D. (2016a). Time together - Time apart. In, Bang, J. \& Winther-Lindqvist, D. (Eds.). Nothingness - philosophical insights into psychology, Transaction Publishers. 143169

Winther-Lindqvist, D. (2016b). Hope as fantasy: An Existential Phenomenology of Hoping in light of Parental Illness, in The Psychology of Imagination: History, Theory and New Research Horizons: NIELS BOHR PROFESSORSHIP LECTURES IN CULTURAL PSYCHOLOGY (Edited by B. Wagoner, I. Bresco and S.H. Awad). 151-173

Woodring, L.A. et al. (2005). Qualitative investigation of adolescents experiences with parental HIV/AIDS. American Journal of Orthopsychiatry, vol. 75. nr. 4. (658-675) https://doi. org/10.1037/0002-9432.75.4.658 